\title{
PENINGKATAN KEAKTIFAN BELAJAR DALAM PEMBELAJARAN SEJARAH MELALUI METODE TEAMS GAMES TOURNAMENT (TGT) DENGAN MEDIA MONOPOLI PADA PESERTA DIDIK KELAS X IPS 2 SMA NEGERI 1 GODEAN
}

Oleh:

Yermia Rendy Suryadinata

Universitas Negeri Yogyakarta

Email: yermiars@gmail.com

\section{ABSTRAK}

Penelitian ini bertujuan untuk (1) mengetahui bagaimana upaya meningkatkan keaktifan belajar peserta didik kelas X IPS 2 SMA Negeri 1 Godean dalam pembelajaran sejarah melalui metode Teams Games Tournament (TGT) dengan media monopoli, (2) untuk mengetahui kelebihan dari penerapan metode Teams Games Tournament (TGT) dengan media monopoli pada peserta didik kelas X IPS 2 SMAN 1 Godean. Penelitian ini merupakan Penelitian Tindakan Kelas (PTK) yang terjadi 2 siklus. Setiap siklus terdiri atas perencanaan, pelaksanaan, pengamatan, dan refleksi. Teknik pengumpulan data diperoleh melalui observasi, angket dan juga catatan penelitian. Analisis data menggunakan analisis kualitatif yang mencakup reduksi data, penyajian data, dan penarikan kesimpulan. Hasil penelitian menunjukkan bahwa (1) Penerapan metode Teams Games Tournament (TGT) dengan media monopoli dapat meningkatkan keaktifan peserta didik kelas X IPS 1 SMAN 1 Godean. Peningkatan keaktifan pada siklus I sebesar $15.6 \%$ terjadi dari $59.55 \%$ menjadi $75.15 \%$. Peningkatan pada siklus II sebesar $6.29 \%$ terjadi dari $75.15 \%$ menjadi $81.44 \%$. Kelebihan dari penerapan metode Teams Games Tournament (TGT) dengan media monopoli antara lain peserta didik lebih aktif dalam pembelajaran, menumbuhkan tanggung jawab peserta didik terhadap kelompok maupun diri sendiri, dan melatih kerja sama dengan peserta didik lain.

Kata kunci: keaktifan, peserta didik, metode, teams games tournament (tgt).

\section{ABSTRACT}

This study aims to (1) find out how to improve learning activeness of students of class $X$ IPS 2 SMA Negeri 1 Godean in learning history through Teams Games Tournament (TGT) method with monopoly media, (2) to know the advantages of application of Teams Games Tournament (TGT) with the monopoly media on the students of class X IPS 2 SMAN 1 Godean. This study is a Classroom Action Research (PTK) which occurs 2 cycles. Each cycle consists of planning, execution, observation, and reflection. Technique of collecting data obtained through observation, questionnaire and also research note. Data analysis uses qualitative analysis that includes data reduction, data presentation, and conclusion. The results showed that (1) Application of Teams Games Tournament (TGT) method with monopoly media can improve the learner activity of class X IPS 1 SMAN 1 Godean. Increased activity in the first cycle of $15.6 \%$ occurred from $59.55 \%$ to $75.15 \%$. The increase in cycle II of $6.29 \%$ occurred from $75.15 \%$ to 81.44\%. The advantages of applying the Teams Games Tournament (TGT) method with the monopoly media include learners more actively in learning, raising the responsibility of learners to groups and themselves, and training cooperation with other students.

Keywords: liveliness, learners, methods, teams games tournament (tgt). 


\section{PENDAHULUAN}

Banyak metode pembelajaran yang bisa digunakan dalam proses belajar interaktif di kelas, namun pemakaian metode pembelajaran pada umumnya masih terpaku pada satu metode saja yang membuat peserta didik mengalami kejenuhan dan kebosanan dalam proses belajar. Inilah yang menyebabkan motivasi, partisipasi, keaktifan dan minat belajar peserta didik rendah dalam pembelajaran Sejarah di kelas dan belum menunjukkan hasil yang optimal. Pembelajaran sejarah memiliki fungsi untuk membangkitkan minat kepada sejarah tanah airnya dan mendapatkan inspirasi sejarah dari kisahkisah kepahlawanan maupun peristiwaperistiwa tragedi nasional, memberi pola berpikir ke arah rasionalitas-kritis-empiris, dan mengembangkan sikap mau menghargai nilai-nilai kemanusiaan (Kartodirdjo, 1992: 43).

Masih ada guru menggunakan metode pembelajaran yang monoton, metode pembelajaran sejarah semacam ini yang menjadikan pelajaran sejarah membosankan, sebagai contoh dalam pembelajaran sejarah hanya menggunakan metode diskusi saja. Awal menggunakan diskusi dalam pembelajaran memang akan menghidupkan suasana kelas, karena diskusi merupakan hal baru dan peserta didik akan terpacu untuk mencari sumber sebanyak mungkin untuk belajar. Akan tetapi jika setiap pertemuan hanya konsen pada diskusi semakin lama peserta didik akan jenuh dan menjadi asal dalam melakukan diskusi, misalnya disaat guru mencari sumber belajar peserta didik akan mencari jalan pintas untuk mendapatkan sumber belajar tersebut yang tadinya giat untuk mencari dan membaca buku beralih dengan menggunakan ringkasan dari internet sebagai sumber utama, yang mana hanya kurang dalam jika akan dilakukan analisis.

Menurut Kamus Besar Bahasa Indonesia, kata aktif memiliki arti giat (bekerja, berusaha), sedangkan keaktifan memiliki arti suatu kegiatan. Seorang guru perlu untuk memperhatikan keaktifan peserta didik supaya proses pembelajaran yang berlangsung memberikan hasil yang baik. Keaktifan dari peserta didik merupakan hal paling mendasar yang diperlukan dalam proses pembelajaran. Berlakunya kurikulum 2013 menuntut keaktifan peserta didik dalam kegiatan pembelajaran, dimana sentral pembelajaran ada dalam diri peserta didik dan guru berperan sebagai mentor sekaligus menggiring peserta didik untuk mampu mencapai target pembelajaran. Suasana kelas yang kondusif ataupun pasif bergantung pada keaktifan peserta didik yang ada di kelas tersebut.

Perubahan dan perkembangan pendidikan di Indonesia sangatlah tampak setelah diberlakukan kurikulum 2013 pada sistem pendidikan dari tingkat dasar sampai ketingkat lanjut. Melihat kegiatan pembelajaran pada kurikulum sebelumsebelumnya peran guru sebagai sentral pembelajaran yang hampir selalu menggunakan metode pembelajaran konvensional. Dewasa ini secara perlahan namun pasti sentral pembelajaran beralih pada peserta didik, dimana peserta didik memiliki peran yang lebih besar dalam kegiatan pembelajaran. Pembelajaran aktif bertujuan untuk mengoptimalkan penggunaan semua potensi yang dimilki oleh anak didik, sehingga semua anak didik dapat mencapai hasil belajar yang memuaskan sesuai dengan karakteristik pribadi yang mereka miliki (Suprijono 2010:6). Peran aktif peserta didik dalam kegiatan pembelajaran dapat memberikan 
pengalaman nyata, karena paserta didik secara maksimal menggunakan kemampuannya untuk mempelajari dan memecahkan permasalahan yang ditemui dari proses pembelajaran. Hal ini menjadi nilai tambah dalam pengalaman yang diperoleh peserta didik dalam berinteraksi. Peran guru tidak serta merta hanya diam mengamati, akan tetapi guru memiliki kewajiban untuk memberikan motivasi dan memfasilitasinya tanpa mendominasi, memberikan kesempatan untuk berpartisipasi aktif, membantu dan mengarahkan siswanya untuk mengembangkan bakat dan minat mereka melalui proses pembelajaran yang terencana.

Guru berusaha menciptakan suasana dan lingkungan belajar yang kondusif sehingga dapat memaksimalkan kemampuan peserta didik dalam menggali pengetahuan dan memecahkan masalah yang ada. Salah satu bentuk usaha guru dalam menciptakan suasana dan lingkungan belajar yang kondusif adalah melalui penggunaan metode pembelajaran yang tepat. Metode pembelajaran yang tepat dapat membuat peserta didik lebih mudah menerima pengetahuan yang diberikan oleh guru.

Permasalahan di atas juga dialami oleh peserta didik kelas X IPS 2 SMA Negeri 1 Godean. Berdasarkan observasi, peneliti menemukan permasalahan klasik dan sering terjadi seperti kurang optimalnya keaktifan peserta didik dalam kegiatan pembelajaran sejarah. Pelajaran Sejarah Indonesia untuk kelas X IPS 2 dijadwalkan pada ke-7 s/d ke-8 atau jam terakhir, sedangkan sebelumnya jadwal pelajaran olahraga dilaksanakan selama 3 jam pelajaran dari jam ke-4 s/d ke-6. Adapun penggunaan metode pembelajaran yang kurang bervariatif dan berulang-ulang membuat peserta didik menjadi jenuh. Sebagai contoh dalam kegiatan pembelajaran guru secara terus-menerus menggunakan metode diskusi, maka diskusi yang seharusnya dapat menarik perhatian dan menunjukkan keaktifan peserta didik hanya akan didominasi beberapa peserta didik saja. Pertanyaan yang muncul adalah bagaimana dengan peserta didik yang lain yang kurang berpartisipasi dalam kegiatan diskusi? Hal ini sangat dipengaruhi oleh peran guru sebagai mentor sekaligus motivator guna menumbuhkan keaktifan dalam diri peserta didik Kejenuhan menjadi salah satu faktor kurangnya keaktifan peserta didik dalam melaksanakan kegiatan pembelajaran, terlebih mata pelajaran sejarah. Mata pelajaran sejarah menjadi momok jika kegiatan pembelajarannya berlangsung saat jam terakhir dengan berbagai macam alasannya. Hal ini dapat dilihat dari keaktifan peserta didik dalam bertanya, menanggapi, memberi jawaban, dan berpendapat masih rendah. Kemampuan bertanya dan berpendapat peserta didik masih cenderung rendah. Hal tersebut dilihat saat pembelajaran tidak ada peserta didik yang bertanya atau mengemukakan pendapatnya.

Upaya peningkatan keaktifan belajar peserta didik dalam pembelajaran, salah satunya dengan cara pemilihan metode pembelajaran yang tepat dan menarik. Kondisi kelas perlu direncanakan dan dibangun oleh guru menggunakan metode pembelajaran yang tepat dan menarik, sehingga keaktifan peserta didik dapat ditingkatkan. Salah satu metode pembelajaran yang menarik adalah metode pembelajaran Teams Games Tournament (TGT).

Metode pembelajaran TGT merupakan kegiatan belajar peserta didik yang dilakukan secara berkelompok untuk mencapai tujuan pembelajaran. Penggunaan TGT mendorong peserta didik untuk aktif 
dan terlibat langsung dalam pembelajaran. Kondisi kelas yang menggunakan metode TGT akan menjadi menyenangkan, dimana peserta didik dibagi dalam beberapa kelompok dan diberi materi yang telah dirancang oleh guru dan dilanjutkan dengan kompetisi antar tim yang dikemas dalam bentuk permainan atau games.

Berdasarkan uraian di atas, diperoleh gambaran permasalahan yang terjadi, maka peneliti tertarik untuk membuat penelitian tindakan kelas yang terfokus mengenai penerapan metode Teams Games Tournament dengan menggunakan media Monopoli terhadap peningkatan keaktifan belajar sejarah peserta didik dengan judul "Upaya Meningkatkan Keaktifan Belajar Peserta Didik Kelas X IPS 2 Di SMA Negeri 1 Godean, Sleman, DIY dalam Pembelajaran Sejarah melalui Metode Teams Games Tournament (TGT) dengan Media Monopoli pada Tahun Ajaran 2017/2018".

\section{METODE PENELITIAN}

Penelitian ini merupakan penelitian tindakan kelas. Penelitian dilaksanakan di SMAN 1 Godean, yang berada di jalan Sidokarto no. 5 Godean Sleman. Sekolah ini satu-satunya sekolah menengah atas negeri yang berada di kecamatan Godean Sleman. Penelitian dilaksanakan selama bulan 28 September 2017 sampai 30 November 2017 pada semester gasal tahun ajaran 2017/2018. Penelitian PTK di khususkan pada peserta didik kelas X IPS 2 SMA Negeri 1 Godean, dengan jumlah 32 peserta didik yang terdiri dari peserta didik laki-laki dan peserta didik perempuan. Penelitian tindakan kelas adalah penelitian yang dilakukan oleh guru di dalam kelasnya secara kolaboratif dan partisipatif untuk memperbaiki kinerja pendidik menyangkut kualitas proses pembelajaran, dan meningkatkan hasil belajar peserta didik, baik dari aspek akademik maupun nonakademik, melalui tindakan reflektif dalam bentuk siklus (Saur, 2014: 19). Desain tindakan yang digunakan adalah model Kemmis dan Mc. Taggart yang dapat diilustrasikan dalam gambar di bawah ini.

Gambar Desain Penelitian Tindakan Kelas

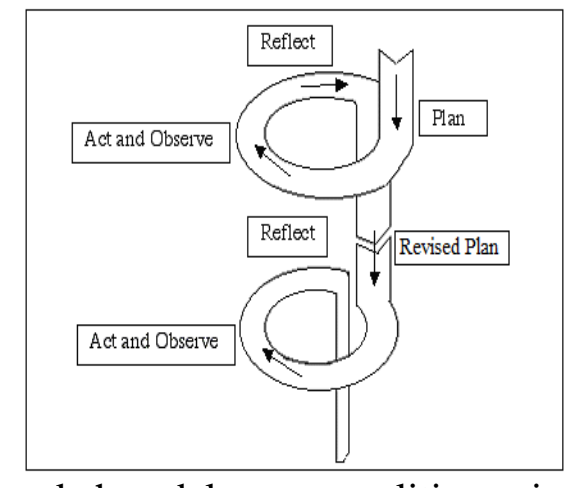

Langkah-langkah dalam penelitian ini adalah:

Perencanaan, meliputi:

- Membuat instrumen pembelajaran.

- Membuat instrument observasi untuk mengamati keaktifan peserta didik dan menilai penerapan model TGT.

\section{Pelaksanaan/Tindakan}

Melaksanakan kegiatan pembelajaran sesuai langkah-langkah yang telah direncanakan. Pelaksana tindakan ini adalah peneliti dan observer.

\section{Pengamatan/Observasi}

Kegiatan observasi dilakukan oleh guru dibantu dengan seorang observer (teman) selama proses pembelajaran berlangsung untuk mengamati: Aktifitas peserta didik dalam proses pembelajaran, Interaksi gurupeserta didik dan antarpeserta didik, dan Proses penggunaan model TGT.

Refleksi 
Peneliti melakukan refleksi terhadap proses belajar, keaktifan belajar peserta didik, dan hasil penilaian pada siklus yang telah berlalu dan menyusun perbaikan untuk kegiatan pembelajaran pada siklus berikutnya.

Instrumen penelitian yaitu alat atau fasilitas yang digunakan oleh peneliti dalam mengumpulkan data agar pekerjaan lebih mudah dan hasilnya baik, lebih cermat, lengkap dan sistematis. (Suharsimi Arikunto : 2002). Sedangkan Sugiyono (2006) mengemukakan bahwa dalam penelitian kualitatif instrumen utamanya adalah peneliti sendiri, namun selanjutnya setelah fokus penelitian menjadi jelas maka kemungkinan akan dikembangkan instrumen penelitian sederhana yang diharapkan dapat melengkapi data dan membandingkan dengan data yang telah ditemukan melalui observasi, angket, dan wawancara.

Teknik analisis data dalam penelitian ini menggunakan analisis deskriptif. Data primer dan sekunder yang diperoleh akan diolah dan disajikan dalam bentuk tabel frekuensi, diagram, dan tabel silang. Data yang diperoleh dari penelitian yang tersaji dalam bentuk tabel frekuensi, diagram, dan tabel silang tersebut selanjutnya akan dianalisis secara deskriptif. Analisis deskriptif dilakukan dengan cara peneliti merefleksi hasil observasi terhadap proses pembelajaran yang dilaksanakan guru dan peserta didik di dalam kelas. Hal ini dimaksudkan untuk menjelaskan dan menggambarkan data dengan tujuan menguji hipotesis tindakan agar diperolehsuatu kesimpulan tentang peningkatan keaktifan peserta didik setelah penerapan metode Teams Games Tournament (TGT) dengan media Monopoli.

Kriteria keberhasilan tindakan dalam penelitian ini adalah meningkatnya keaktifan belajar peserta didik dalam proses pembelajaran pada siklus 1 dan siklus 2 .
Penentuan kriteria untuk keberhasilan tindakan sangat penting untuk mengukur keberhasilan tindakan kelas. Indikator keberhasilan PTK yang ditetapkan oleh peneliti yaitu bila peserta didik memenuhi persentase keaktifan belajar $75 \%$ atau mencapai kriteria baik. Apabila peserta didik sudah memenuhi indikator keberhasilan tersebut maka dapat dikatakan bahwa peserta didik memenuhi aspek berikut: (1) Peserta didik aktif mendengarkan penjelasan guru dan mencatat, (2) Peserta didik aktif mengerjakan tugas yang diberikan guru, (3) Peserta didik berpartisipasi aktif untuk bertanya, berpendapat dan menjawab pertanyaan, dan (4) Peserta didik berpartisipasi aktif dalam diskusi kelompok.

\section{HASIL PENELITIAN DAN PEMBAHASAN}

Upaya meningkatkan keaktifan belajar peserta didik kelas X IPS 2 SMA Negeri 1 Godean dalam pembelajaran sejarah melalui metode Teams Games Tournament (TGT) dengan media monopoli tahun ajaran 2017/2018.

\section{Kegiatan Pra-Tindakan}

Tahap pertama yang dilakukan peneliti sebelum melaksanakan penelitian adalah meminta ijin kepada kepala sekolah dan guru mata pelajaran Sejarah Indonesia yang bersangkutan untuk melakukan observasi kelas. Ibu Dra. Laily Wahyuningsih merupakan guru pamong peneliti untuk melakukan kegiatan penelitian tindakan kelas. Selanjutnya peneliti berdiskusi dengan guru pamong mengenai permasalahan-permasalahan yang terjadi selama kegiatan pembelajaran sejarah berlangsung dan mengenai rencana pembelajaran sejarah dengan menggunakan metode Teams Games Tournament (TGT) dengan media monopoli. 
Setelah berdiskusi dengan Ibu Laily selaku guru sejarah Indonesia, kemudian melakukan observasi untuk melihat secara langsung permasalahan yang muncul dalam pembelajaran sejarah Indonesia di kelas $X$ IPS 2. Dari diskusi dan observasi pada 28 September 2017, diambil kesimpulan bahwa saat pembelajaran sejarah Indonesia di kelas $X$ IPS 2 tingkat keaktifan peserta didik terlihat kurang optimal. Ketika pembelajaran sejarah terlihat peserta didik kurang aktif, tidak semua peserta didik ikut berpartisipasi, dan kegiatan tanya jawab seperti ala kadarnya. Dalam kegiatan diskusi tidak sedikit peserta didik yang terlalu mengandalkan teman satu kelompoknya yang dianggap pintar.

Permasalahan yang muncul tidak lepas dari faktor eksternal dari peserta didik sebagai berikut: 1) Mata pelajaran sejarah Indonesia di kelas X IPS 2 mendapat jadwal jam ke-7 dan 8 (jam terakhir), 2) Sebelumnya dari jam ke-4 s/d 6 dilaksanakan pelajaran PJOK. Dua hal tersebut adalah alasan yang tidak bisa dipungkiri lagi apabila peserta didik di kelas X IPS 2 tingkat keaktifan menjadi kurang optimal dalam pembelajaran sejarah Indonesia. Melihat permasalahan yang dihadapi, maka perlu diterapkan metode pembelajaran yang bervariasi, karena dengan metode pembelajaran yang bervariasi hendaknya peserta didik menjadi tertarik dan termotivasi terhadap pembelajaran sejarah. Saat peserta didik tertarik dan termotivasi, maka akan berpengaruh terhadap keaktifan peserta didik terhadap pembelajaran sejarah.

Metode pembelajaran baru yang dipilih sebagai upaya meningkatkan keaktifan peserta didik adalah Teams Games Tournament (TGT) dengan media monopoli. Tujuan utama yang perlu ditekankan dalam penggunaan metode TGT adalah mengubah mindset mapel sejarah yang membosankan dan menepis anggapan bahwa mapel sejarah tidak terlalu penting karena tidak masuk dalam mapel yang diujikan pada Ujian Nasional. TGT sebagai metode baru di kelas $\mathrm{X}$ IPS 2 hendaknya mampu membuat pesera didik menjadi tertarik dan termotivasi dalam pembelajaran sejarah sehingga dapat membuat peserta didik menjadi aktif. Berdasarkan hasil observasi keaktifan belajar pra-tindakan yang telah disajikan, dapat diketahui bahwa rata-rata persentase keaktifan belajar sejarah peserta didik kelas $\mathrm{X}$ IPS 2 masih belum mencapai kriteria keberhasilan yang telah ditetapkan yaitu persentase keaktifan belajar $75 \%$.

\section{Siklus 1}

Perencanaan (Planing)

Pada tahap perencanaan tindakan

ini, dilakukan persiapan kegiatan pembelajaran sejarah dengan menggunakan metode Teams Games Tournament (TGT) dengan media monopoli. Komponenkomponen yang perlu disiapkan dalam perencanaan siklus 1 antara lain: RPP, media pembelajaran, dan instrument penilaian.

Pelaksanaan Tindakan (Acting)

Pelaksanaan siklus I dilakukan selama dua kali pertemuan sebanyak 4 jp $\times 45$ menit. Siklus 1 pertemuan 1 dilaksanakan pada tanggal 5 Oktober 2017 mulai pukul 12.30-14.00 WIB. Pada pertemuan 1 dilakukan kegiatan diskusi dan presentasi. Materi yang yang disampaikan pada pertemuan 1 yaitu perkembangan bumi, teori perkembangan makhluk hidup dan jenis-jenis manusia purba. Siklus 1 pertemuan 2 dilaksanakan pada tanggal 12 Oktober 2017 mulai pukul 12.30-14.00 WIB. Pada pertemuan 2 dilakukan kegiatan review materi dan game monopoli sejarah.

Pengamatan/ Observasi 
Berdasarkan pengamatan yang dilakukan oleh peneliti dan observer pada siklus 1 diperoleh kesimpulan sebagai berikut.

Pengamatan Terhadap Peneliti.

Berdasarkan hasil observasi yang dilakukan pada siklus 1, peneliti telah membuat RPP dengan baik. RPP telah dibuat dengan lengkap sesuai dengan kompetensi inti maupun kompetensi dasarnya. Selama proses pembelajaran dengan menggunakan model pembelajaran Teams Games Tournament (TGT) dengan media monopoli, peneliti telah melakukan sebagian besar langkah dalam pembelajaran, namun terdapat kendala dimana ada beberapa peserta didik yang tidak fokus pada saat pembelajaran. Metode pembelajaran Teams Games Tournament (TGT) dengan media monopoli baru pertama kali diterapkan di kelas X IPS 2 sehingga peserta didik banyak yang kurang paham dengan langkah-langkahnya. Setelah dilakukan beberapa kali percobaan peserta didik segera memahami, karena secara umum peraturannya sama dengan permainan monopoli biasa hanya diberi tambahan untuk memunculkan keaktifan peserta didik. Penguasaan kelas sudah cukup bagus meskipun kondisi kelas seringkali terlalu ramai.

Pengamatan terhadap Peserta didik. Berdasarkan

observasi, keterlaksanaan pembelajaran sejarah menggunakan model TGT secara umum sudah terlaksana dengan baik. Langkahlangkah pembelajaran yang telah dilaksanakan oleh peneliti berjalan dengan lancar, namun masih ada sedikit kendala terkait dengan manajemen waktu. Menurut observer, karena keterbatasan waktu sehingga kegiatan pembelajaran terkesan terburu-buru dan kurang maksimal. Peneliti dalam melaksanakan kegiatan pembelajaran masih belum bisa mengatur waktu dengan efektif. Hal tersebut diamati pada kegiatan akhir pembelajaran guru terkesan terburuburu ketika menyimpulkan materi, karena pada saat membuat kesimpulan waktu yang tersisa sedikit menjelang jam pelajaran berakhir.

Berdasarkan tabel hasil observasi keaktifan belajar siklus 1, rata-rata persentase pada 6 aspek keaktifan sudah mencapai kriteria keberhasilan yang ditetapkan, yaitu $75 \%$. Akan tetapi baru mencapai angka sebesar 75.26\%. Setelah di gunakan metode TGT dengan media monopoli terjadi peningkatan yang cukup baik sebesar $15.71 \%$ dari hasil observasi sebelumnya sebesar $59.55 \%$.

Refleksi

Berdasarkan hasil penelitian pada siklus 1 kegiatan pembelajaran dengan menggunakan metode Teams Games Tournament (TGT) dengan media monopoli diperoleh dari hasil observasi yang dilakukan oleh observer selama siklus 1 berlangsung dan hasil pengisian angket oleh peserta didik sesudah dilaksanakannya metode Teams Games Tournament (TGT) dengan media monopoli. Peneliti menemukan beberapa kendala yang dihadapi saat kegiatan pembelajaran menggunakan metode TGT, yaitu: (1) Guru perlu melakukan manajemen waktu yang lebih baik, dan (2) Guru belum optimal dalam memotivasi peserta didik untuk lebih aktif dalam kegiatan pembelajaran, terutama untuk aspek oral activities. Berdasarkan hasil refleksi dari kegiatan pembelajaran pada siklus 1, maka peneliti perlu melakukan perbaikan manajemen waktu agar pelaksanaan kegiatan pembelajaran dapat berlangsung sesuai perencanaan yang telah dibuat. Peneliti juga menyadari perlunya pemberian motivasi pada peserta didik untuk aktif bertanya, menjawab, 
menyampaikan pendapat, dan memberikan tanggapan.

Siklus II

Perencanaan (Planing)

Sama seperti tahap perencanaan pada siklus 1, peneliti membuat komponenkomponen yang perlu disiapkan dalam perencanaan siklus 2 antara lain: RPP, media pembelajaran, dan instrument penilaian. Dari hasil siklus 1, peneliti merencanakan pembelajaran Metode pembelajaran Teams Games Tournament (TGT) dengan media monopoli untuk siklus 2. Pada siklus 2 ditambahkan aturan tentang pembelian "rumah sebagai tanda kepemilikan petak", sehingga pada siklus 2 Teams Games Tournament (TGT) dengan media monopoli menuntut masing-masing tim untuk lebih aktif dengan membuat pertanyaan sekaligus pertanyaan diperuntukkan bagi kelompok lain yang masuk pada petak yang terdapat bangunan "rumah".

Pelaksanaan Tindakan (Action)

Pelaksanaan siklus 2 dilakukan selama dua kali pertemuan sebanyak 4 jp $\times 45$ menit. Siklus 2 pertemuan 1 dilaksanakan pada tanggal 26 Oktober 2017 mulai pukul 12.30-14.00 WIB. Pada pertemuan 1 dilakukan kegiatan diskusi dan presentasi. Materi yang yang disampaikan pada pertemuan 1 yaitu kehidupan masa berburu, meramu, masa bercocok tanam dan masa perundagian, dan hasil-hasil budaya manusia purba pada zaman batu dan zaman logam. Siklus 2 pertemuan 2 dilaksanakan pada tanggal 2 November 2017 mulai pukul 12.30-14.00 WIB. Pada pertemuan 2 dilakukan kegiatan review materi dan game monopoli sejarah.

Pengamatan/ Observasi

Berdasarkan pengamatan yang dilakukan oleh peneliti dan observer pada siklus 2 diperoleh kesimpulan sebagai berikut.

Pengamatan Terhadap Peneliti

Berdasarkan hasil observasi yang dilakukan pada siklus 2, peneliti telah membuat RPP dengan baik. RPP telah dibuat dengan lengkap sesuai dengan kompetensi inti maupun kompetensi dasarnya. Selama proses pembelajaran dengan menggunakan model pembelajaran Teams Games Tournament (TGT) dengan media monopoli, peneliti telah melakukan sebagian besar langkah dalam pembelajaran, namun terdapat kendala dimana ada beberapa peserta didik yang tidak fokus pada saat pembelajaran. Metode pembelajaran Teams Games Tournament (TGT) dengan media monopoli baru pertama kali diterapkan di kelas X IPS 2 sehingga peserta didik banyak yang kurang paham dengan langkah-langkahnya. Setelah dilakukan beberapa kali percobaan peserta didik segera memahami, karena secara umum peraturannya sama dengan permainan monopoli biasa hanya diberi tambahan untuk memunculkan keaktifan peserta didik. Penguasaan kelas sudah cukup bagus meskipun kondisi kelas seringkali terlalu ramai.

Pengamatan terhadap Peserta didik.

Berdasarkan hasil observasi pada siklus 2 menunjukkan adanya peningkatan yang lebih baik dibanding pada siklus 1 . Berdasarkan tabel hasil observasi keaktifan belajar siklus 2, rata-rata persentase pada 6 aspek keaktifan sudah mencapai kriteria keberhasilan yang ditetapkan yaitu $75 \%$, bahkan sudah melebihi. Persentase pada siklus 2 menunjukkan angka sebesar $82.81 \%$. Setelah di gunakan metode TGT dengan media monopoli untuk kedua kalinya terjadi peningkatan yang cukup baik sebesar $7.55 \%$ dari hasil observasi sebelumnya sebesar 75.26\%. Sedangkan hasil angket keaktifan 
belajar siklus 2, rata-rata persentase pada 6 aspek keaktifan sudah mencapai kriteria keberhasilan yang ditetapkan, yaitu $75 \%$ bahkan melebihi. Persentase pada siklus 2 menunjukkan angka sebesar $81.28 \%$. Setelah di gunakan metode TGT dengan media monopoli untuk kedua kalinya terjadi peningkatan yang cukup baik sebesar $6.25 \%$ dari hasil observasi sebelumnya sebesar $75.03 \%$.

Refleksi

Berdasarkan hasil penelitian pada siklus 2 kegiatan pembelajaran dengan menggunakan metode Teams Games Tournament (TGT) dengan media monopoli diperoleh dari hasil observasi yang dilakukan oleh observer selama siklus 2 berlangsung dan hasil pengisian angket oleh peserta didik sesudah dilaksanakannya metode Teams Games Tournament (TGT) dengan media monopoli. Pelaksanaan kegiatan pembelajaran dengan menggunakan metode Teams Games Tournament (TGT) dengan media monopoli pada siklus 2 telah mampu meningkatkan keaktifan belajar peserta didik. Selain permainan yang menyenangkan, serta pemberian reward memberikan motivasi tersendiri untuk masing-masing peserta didik menunjukkan keaktifannya terlebih saat permainan. Hal ini juga memberikan dampak yang kurang baik, karena beberapa terlalu menonjolkan diri saat diskusi untuk memutuskan jawaban dari pertanyaan monopoli.

\section{Pembahasan}

Penelitian yang dilaksanakan dengan menggunakan metode Teams Games Tournament (TGT) dengan media monopoli bertujuan untuk (1) mengetahui penerapan metode Teams Games Tournament (TGT) dengan media monopoli untuk meningkatkan keaktifan belajar peserta didik dalam pembelajaran sejarah di kelas X IPS 2 SMA Negeri 1 Godean tahun ajaran 2017/2018, dan (2) mengetahui kelebihan dari metode Teams Games Tournament (TGT) dengan media monopoli terhadap pembelajaran sejarah. Hasil akhir penelitian ini merupakan pengolahan dari hasil observasi dan hasil angket peserta didik yang dilakukan selama 2 siklus. Data dari penelitian ini Hasil analisis dari penelitian yang dilakukan dengan penerapan metode Teams Games Tournament (TGT) dengan media monopoli dapat disimpulkan sebagai berikut.

Penerapan metode Teams Games Tournament (TGT) dengan media monopoli untuk meningkatkan keaktifan belajar peserta didik dalam pembelajaran sejarah di kelas X IPS 2 SMA Negeri 1 Godean tahun ajaran 2017/2018.

Peningkatan keaktifan belajar peserta didik dengan penerapan metode Teams Games Tournament (TGT) dengan media monopoli secara umum berjalan dengan lancar. Sebelum dilakukan tindakan dengan metode TGT, peserta didik terlihat bosan dengan metode pembelajaran sama yang dilakukan secara terus menerus. Pada saat kegiatan pra-tindakan digunakan model pembelajaran ceramah dan diskusi, hal ini dilakukan untuk mengetahui sejauh mana keaktifan peserta didik dalam mengikuti pembelajaran sejarah.

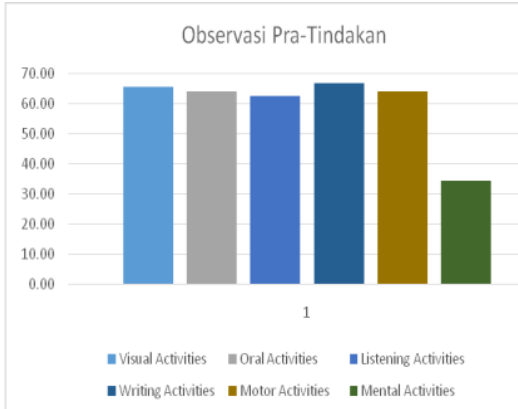

Diagram 1. Hasil Observasi Pra-tindakan 
Berdasarkan diagram di atas menunjukkan 5 aspek sudah dalam kategori aktif namun belum mencapai kriteria, sedangkan 1 aspek masuk dalam kategori sangat tidak aktif. Aspek yang berada dalam kategori sangat tidak aktif adalah mental activities. Indikator dari aspek mental activities adalah 1) ikut memecahkan permasalahan dalam diskusi, 2) menanggapi presentasi atau jawaban. Dari dua aspek ini terlihat peserta didik masih pasif dan enggan untuk menanggapi presentasi kelompok lain. Hasil rata-rata dari kelima aspek sebesar 59.55\%.

Pertama kali digunakan metode Teams Games Tournament (TGT) dengan media monopoli masih perlu diberi stimulan untuk menumbuhkan fokus peserta didik terhadap diskusi yang dirasa sama saja oleh peserta didik. Namun pemberian stimulant yang berulang-ulang cukup memberikan dampak terhadap aktif dan keseriusan dalam mengikuti presentasi kelas. Penerapan metode Teams Games Tournament (TGT) dengan media monopoli pada siklus 1 pertemuan 1, dilaksanakan pada hari kamis, 5 Oktober 2017 mulai pukul 12.30-14.00 WIB. Materi yang yang disampaikan mengenai "Perkembangan Bumi, Teori Perkembangan Makhluk Hidup dan Jenisjenis Manusia Purba". Terdapat kendala dalam pembelajaran dimana ada beberapa peserta didik yang kurang fokus dalam kegiatan pembelajaran dengan alasan lelah karena sebelum pelajaran sejarah ada pelajaran PJOK. Pada pertemuan 1 model pembelajaran diskusi dan presentasi yang dianggap kebanyakan peserta didik sama saja dengan pembelajaran yang lalu. Peran guru sangat dibutuhkan untuk menumbuhkan aktif dengan memberikan stimulan berupa ajakan penggunaan model permainan pada pertemuan berikutnya dengan mengambil materi yang didiskusikan dan dipresentasikan. Dengan pemberian stimulant oleh guru, aktif peserta didik saat diskusi sudah terlihat namun masih ada beberapa peserta didik yang kurang aktif dan takut pada saat proses diskusi dan presentasi.

Siklus 1 pertemuan 2 dilaksanakan pada hari kamis, 12 Oktober 2017 mulai pukul 12.30-14.00 WIB. Pada pertemuan 2 kegiatan pembelajaran dilanjutkan dengan presentasi 2 kelompok terakhir, selanjutnya dilaksanakan Teams Games Tournament (TGT) dengan media monopoli. Tidak sedikit peserta didik yang kurang paham dengan aturan permainan, namun setelah dilakukan beberapa simulasi peserta didik menjadi paham karena peraturan dasarnya tidak berbeda dengan permainan monopoli pada umumnya. Selama permainan monopoli sejarah terlihat peserta didik lebih aktif berdiskusi untuk menjawab pertanyaan ketika bidak berhenti dipetak hasil lemparan dadu dibanding pada saat kegiatan diskusi dan presentasi. Di bawah ini merupakan hasil yang diperoleh dari observasi dan lembar angket.

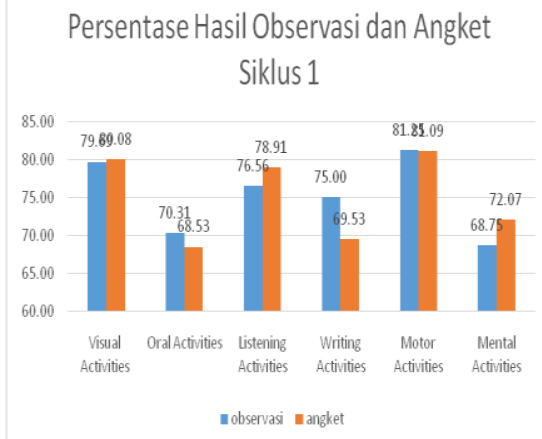

Diagram 2 Hasil Persentase

Hasil Observasi dan Angket Siklus 1

Berdasarkan diagram di atas menunukkan perbedaan persentase yang diperoleh dari hasil observasi dan hasil angket peserta didik, namun setelah dirata-rata menunjukkan hasil ketercapaian kriteria ketuntasan sebesar $75.15 \%$. Hasil tersebut diperoleh dari rata-rata penjumlahan hasil 
observasi sebesar $75.26 \%$ dan hasil angket sebesar $75.03 \%$. Hasil yang dicapai pada siklus 1 sudah mencapai kriteria yang dimaksudkan.

Penerapan metode Teams Games Tournament (TGT) dengan media monopoli pada siklus 2 pertemuan 1, dilaksanakan pada hari kamis, 26 Oktober 2017 mulai pukul 12.30-14.00 WIB. Materi yang yang disampaikan mengenai "Kehidupan Masa Berburu, Meramu, Masa Bercocok Tanam dan Masa Perundagian, dan Hasil-hasil Budaya Manusia Purba pada Zaman Batu dan Zaman Logam". Peserta didik saat kegiatan pembelajaran dengan model diskusi dan presentasi terlihat lebih aktif dibanding pertemuan 1 pada siklus 1 . Hal ini dikarenakan pada pertemuan selanjutnya akan diadakan lagi permainan monopoli sehingga terlihat peserta didik menjadi aktif. Kegiatan diskusi dan presentasi menjadi lebih hidup karena sudah ada peserta didik yang berani menanggapi dalam kegiatan presentasi. Ketika keterlibatan peserta didik dalam belajar lebih optimal, menyebabkan pembelajaran yang berlangsung lebih efektif. Pembelajaran yang sudah efektif akan membuat peserta didik lebih aktif dan kreatif sehingga pembelajaran menjadi lebih menyenangkan.

Siklus 2 pertemuan 2 dilaksanakan pada hari kamis, 2 November 2017 mulai pukul 12.30-14.00 WIB. Pada pertemuan 2 kegiatan pembelajaran dilanjutkan dengan presentasi 2 kelompok terakhir, selanjutnya dilaksanakan Teams Games Tournament (TGT) dengan media monopoli. Peserta didik sangat aktif untuk bermain permainan monopoli sejarah, karena ada hal-hal mengejutkan ketika bidak berhenti di petak Geschiedenis dan Einmalig. Ketika bidak berhenti di petak Geschiedenis dan Einmalig pemain harus mengambil kartu yang didalamnya berisi perintah, ketidakberuntungan dan keberuntungan yang harus dilaksanakan oleh 1 tim. Isi dari kartu perintah, ketidakberuntungan dan keberuntungan seperti: maju 2 petak setelah melakukan 3 instruksi baris-berbaris, menyanyikan lagu anak lalu mundur 1 petak, kartu bebas penjara, kembali ke START dan lain sebagainya. Selain itu diberi kesempatan pembelian rumah sebagai hak milik atas sebuah petak. Tim yang sudah memiliki petak dituntut untuk membuat pertanyaan dan jawaban yang sesuai dengan materi yang dipelajari pada pertemuan sebelumnya.

Persentase Hasil Observasi dan Angket Siklus2

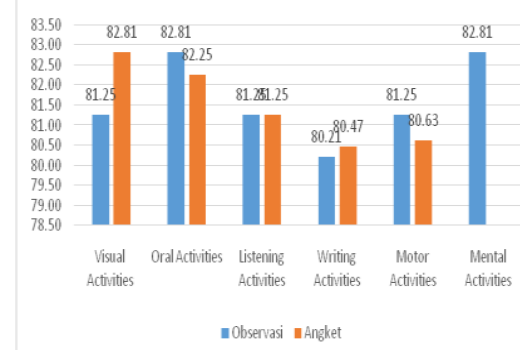

Diagram 3 Hasil Persentase

Hasil Observasi dan Angket Siklus 2 Berdasarkan diagram di atas menunukkan perbedaan persentase yang diperoleh dari hasil observasi dan hasil angket peserta didik, namun setelah dirata-rata menunjukkan hasil ketercapaian kriteria ketuntasan sebesar $81.44 \%$. Hasil tersebut diperoleh dari rata-rata penjumlahan hasil observasi sebesar $81.60 \%$ dan hasil angket sebesar $81.28 \%$.

Aspek motor activities yang mengalami penurunan pada siklus 2 dibanding pada siklus 1 , hal ini dikarenakan guru memberikan kebebasan untuk menentukan giliran untuk bermain monopoli kemudian peserta didik melakukan pergantian pemain berbeda tiap kelompoknya. Contohnya ada tim yang menerapkan pergantian pemain setelah 
melakukan dua atau tiga kali lemparan dadu, hal ini mengakibatkan tidak semua peserta didik mendapatkan porsi yang sama dalam memainkan monopoli sampai waktu yang telah ditentukan habis. Hasil yang dicapai pada siklus 2 sudah melebihi kriteria yang dimaksudkan, meskipun belum optimal. Siklus 2 akan lebih optimal bilamana aturan yang diterapkan sama ketika permainan monopoli pada siklus 1. Alasan guru memberi kebebasan kepada tim adalah untuk melihat sejauh mana kerja sama dan tanggung jawab yang dimiliki oleh masingmasing peserta didik. Kerja sama dan tanggung jawab oleh masing-masing peserta didik sudah menunjukkan hal yang yang positif.

Di bawah ini dapat dilihat persentase peningkatan keaktifan peserta didik yang diperoleh dari hasil pra-tindakan, siklus 1, dan siklus 2 .

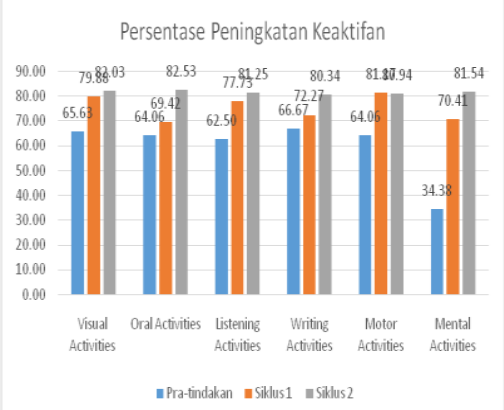

Diagram 4 Persentase

Peningkatan Keaktifan Peserta Didik Berdasarkan diagram di atas dapat diketahui bahwa aspek keaktifan belajar peserta didik yang memiliki nilai tertinggi di siklus 2 adalah aspek oral activities dengan nilai $82.53 \%$. Nilai persentase tersebut masuk dalam kategori sangat aktif. Nilai aspek tersebut besar karena peneliti melakukan motivasi kepada peserta didik dan pengkondisian kelas. Pemberian motivasi mendorong peserta didik untuk aktif dalam kegiatan pembelajaran, peserta didik menjadi tidak segan ataupun takut untuk menyampaikan pertanyaan dan pendapat dalam kegiatan diskusi dan presentasi. Penelitian dihentikan karena waktu tidak memungkinkan untuk diadakan siklus tambahan, terlebih target pencapaian sudah melebihi kriteria ketuntasan.

Kelebihan dari metode Teams Games Tournament (TGT) dengan media monopoli terhadap pembelajaran sejarah di kelas X IPS 2 SMA Negeri 1 Godean. Berdasarkan hasil observasi yang dilakukan oleh observer dan peneliti selama 2 siklus serta hasil angket yang diisi oleh peseerta didik, dapat disimpulkan kelebihan dari penerapan metode Teams Games Tournament (TGT) dengan media monopoli yaitu sebagai berikut.

- Peserta didik menjadi lebih aktif dalam mengikuti pembelajaran karena model pembelajaran ini baru pertama kali diterapkan sehingga memiliki kesan menyenangkan dan menarik perhatian kelas X IPS 2 SMA Negeri 1 Godean tahun ajaran 2017/2018.

- Peserta didik lebih termotivasi untuk lebih aktif dalam kegiatan pembelajaran sejarah.

- Menciptakan suasana pembelajaran yang berbeda dan tidak membosankan.

- Mengasah kemampuan peserta didik dalam pembelajaran sejarah, hal ini didapat dari peserta didik tetap memiliki tanggung jawab individual meski mereka belajar bersama dalam kelompok.

- Melatih peserta didik untuk bekerjasama dengan kelompoknya tanpa membedakan kemampuan akademik, jenis kelamin, suku, ras, dan lain sebagainya.

\section{Pokok Temuan Penelitian}

Data penelitian dilapangan diperoleh dari hasil observasi, wawancara, dan hasil angket minat belajar. Berdasarkan 
hasil dari pencarian data-data tersebut, diperoleh pokok temuan sebagai berikut.

- Mata pelajaran sejarah dianggap membosankan.

- Jadwal mata pelajaran sejarah mempengaruhi tingkat keaktifan peserta didik dalam kegiatan pembelajaran, misalnya pelajaran sejarah ada di jam terakhir.

- Jadwal mata pelajaran sebelum jadwal mata pelajaran sejarah mempengaruhi tingkat keaktifan peserta didik dalam kegiatan pembelajaran, sebagai contoh pelajaran PJOK sebelum pelajaran sejarah mempengaruhi tingkat keaktifan peserta didik.

- Keaktifan belajar peserta didik terhadap pembelajaran sejarah di Kelas X IPS 2 sebelum menerapkan metode Teams Games Tournament (TGT) dengan media monopoli masih belum optimal.

- Guru masih mengandalkan pembelajaran dengan model diskusi biasa.

- Diperlukan model pembelajaran yang menarik untuk mendorong keaktifan peserta didik dalam pembelajaran sejarah.

- Metode Teams Games Tournament (TGT) dengan media monopoli memberikan suasana pembelajaran yang berbeda, menyenangkan dan tidak membosankan.

- Metode Teams Games Tournament (TGT) dengan media monopoli membuat peserta didik lebih aktif dan termotivasi untuk lebih aktif dalam kegiatan pembelajaran sejarah.

\section{PENUTUP}

Berdasarkan hasil penelitian dan pembahasan yang telah diuraikan, maka diperoleh kesimpulan: (1) Penggunaan metode Teams Games Tournament (TGT) dengan media monopoli dapat meningkatkan keaktifan peserta didik kelas X IPS 2 SMA Negeri 1 Godean dalam kegiatan pembelajaran sejarah. Pernyataan tersebut dapat dibuktikan dari perolehan data hasil observasi, angket, dan catatan lapangan yang menunjukkan adanya peningkatan ratarata indikator keaktifan peserta didik pada tiap siklus hingga mencapai bahkan melebihi kriteria keberhasilan tindakan yang ditentukan, (2) Siklus 1 menunjukkan bahwa rata-rata indikator keaktifan peserta didik sudah mencapai kriteria keberhasilan, sedangkan pada siklus 2 sudah melebihi kriteria keberhasilan keaktifan. Metode Teams Games Tournament (TGT) dengan media monopoli yang dipilih memang sesuai digunakan untuk meningkatkan keaktifan peserta didik. Selain itu, metode yang digunakan belum pernah digunakan sebelumnya pada kegiatan pembelajaran sejarah, (3) Kelebihan metode Teams Games Tournament (TGT) dengan media monopoli dalam pembelajaran sejarah yakni meningkatnya keaktifan peserta didik dalam kegiatan pembelajaran dikelas, dan (4) Peserta didik terlibat aktif dalam pembentukan kelompok, diskusi kelompok bahkan sampai presentasi hasil kerja kelompok dikarenakan langkah-langkah metode Teams Games Tournament (TGT) dengan media monopoli dari diskusi dan presentasi sampai pada permainan monopoli diperlukan keaktifan dari peserta didik.

\section{UCAPAN TERIMA KASIH}

Penulis mengucapkan terima kasih kepada berbagai pihak yang telah membantu terlaksananya penelitian ini. Tak lupa, penulis juga menyampaikan ucapan terima kasih kepada dewan redaksi Jurnal Istoria terbitan Pendidikan Sejarah, Fakultas Ilmu Sosial, Universitas Negeri Yogyakarta atas kesempatan yang diberikan sehingga tulisan ini dapat dipublikasikan pada edisi September 2017. 


\section{DAFTAR PUSTAKA}

Ali, R. Moh. (2005). Pengantar Ilmu Sejarah Indonesia. Yogyakarta: Pelangi Aksara.

Arikunto, Suharsimi. (2003). Dasar-dasar Evaluasi Pendidikan. Jakarta: Bumi Aksara.

Arikunto, Suharsimi. (2010). Penelitian Tindakan Kelas (Untuk Guru, Kepala Sekolah dan Pengawas). Malang: Aditya Media Publishing.

Buzan, T. (2013). Buku Pintar Mind Map. Jakarta: Gramedia.

Huda, Miftahul. (2015). Cooperative Learning: Metode, Teknik. Struktur, dan Model Terapan. Yogyakarta: Pustaka Pelajar.

Kartodirdjo, Sartono. (1992). Pendekatan Ilmu Sosial dalam Metodologi Sejarah. Jakarta: Gramedia.

Kuntowijoyo, Kuntowijoyo.(1999). Pengantar Ilmu Sejarah. Yogkarta : Bentang Budaya.

Lie, Anita. (2004). Cooperative Learning: Mempraktikkan Cooperative Learning di Ruang-ruang Kelas. Jakarta: PT. Gramedia.

Madya, Suwarsih. (2007). Teori dan Praktik Penelitian Pendidikan (Action Research). Bandung: Alfabeta.

Mulyasa, E. (2009). menjadi Guru Profesional Menciptakan Pembelajaran Kreatif dan Menyenangkan. Bandung: Remaja Rosdakarya.

Sardiman A. M. (2004). Mengenal Sejarah. Yogyakarta: Bigraf Publishing. (2004). Interaksi dan

Motivasi Belajar Mengajar. Jakarta: PT. Raja Grafindo Persada.

Slavin, Robert E. (2005). Terjemahan: Cooperatif Learning, Teori, Riset dan Praktik. Bandung : Nusa Media.
(2008). Cooperative Learning Teori Riset dan Praktik. Bandung: Nusa Media

Slameto, Slameto. (2003). Belajar dan Faktor-Faktor Yang mempengaruhinya. Jakarta: Rineka Cipta.

Sugihartono, dkk. (2007). Psikologi Pendidikan. Yogyakarta: UNY Press.

Sugiyono, Sugiyono (2006). Metodologi Penelitian Pendidikan"Pendekatan Kuantitatif,Kualitatif dan $R \& D$ ". Bandung : ALFABETA.

Surya, Mohamad. (2004). Psikologi Pembelajaran dan Pengajaran. Bandung: Pustaka Bani Quraisy.

Suryani, N \& Agung S, L. (2012). Strategi Belajar Mengajar. Yogyakarta: Ombak.

Trianto, Trianto. (2010). Model Pembelajaran Terpadu. Jakarta: Bumi Aksara.

Wiriatmadja, Rochmawati. (1998). Landasan Folosofis Pembelajaran Sejarah (SMU) Tantangan dan Harapan: Simposium Pembelajaran Sejarah. Jakarta: Depdikbud. 